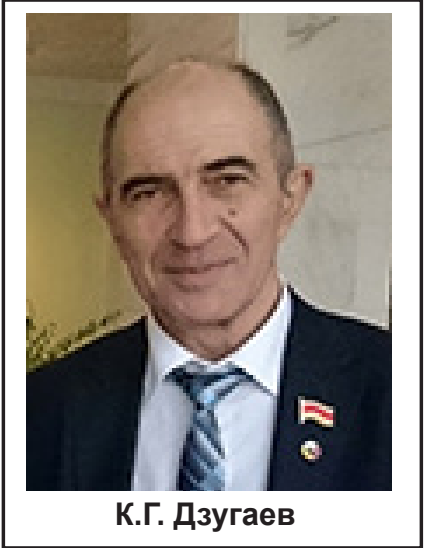

В июне сего года ко мне обратился г-н Марк Юнге с просьбой прокомментировать главы «Этнос и террор» и «Дискуссия» подготовленного им и Берндом Бонвичем двухтомника «Большевистский порядок в Грузии» (Москва, 2015). Том 1 называется «Большой террор в маленькой кавказской республике», том 2 - «Документы и статистика». Издание приурочено к 10-летию Германского исторического института в Москве, под эгидой Международного совета научных проектов и издательских программ Ассоциации исследователей Российского общества (АИРО), руководитель Геннадий Бордюгов, гендиректор Андрей Макаров; в совет, имеющий весьма сильный состав зарубежных представителей, в частности, входят Людмила Гатагова (Институт российской истории РАН) и Алан Касаев (Московский государственный лингвистический университет, ныне работает главным редактором газеты «Северная Осетия»).

Данная статья подготовлена как научно-публицистический вариант текста, представленного мною на рассмотрение г-на М. Юнге и, как мне сообщили, включенного в книгу «Грузия в пути. Тени сталинизма», которая в скором времени будет издана ${ }^{1}$ в продолжение темы. Надеюсь получить ее и организовать в Южной Осетии презентацию, учитывая ее актуальность для осетино-грузинских отношений.

Исследователи выстраивают свою работу над двухтомником в соответствии с принятыми в исторической науке правилами, т. е. это сугубо академическое исследование, поэтому первый том предваряет достаточно развернутое рассмотрение состояния дел в историографии Большого террора (этот термин не принадлежит авторам двухтомника, и у меня вызывает некоторые сомнения его научная правомерность; тем не менее считаю возможным его использование в данном тексте) в Грузии. Констатируя, что повышенный интерес к репрессиям в Грузии обусловлен во многом или в основном тем, что именно из этой кавказской республики происходит целый ряд большевистских руководителей СССР, начиная с И. Сталина, авторы в отношении грузинской источниковедческой базы вынуждены сделать вывод о том, что она представляет собой «нетронутую целину»: «Практически нетронутая целина в области исследований Большого террора в Грузии объясняется прежде всего неготовностью общества» [2, с. 27 ]. Но не только: архивные документы интересующего периода были уничтожены во время гражданской войны 1991 г., когда в Тбилиси в ходе столкновений было сожжено здание КГБ, где хранились документы ОГПУ-НКВД 1920-1930 гг., а также сожжен и архив МВД. Тем не менее, по мнению авторов, сохранившихся документов вполне достаточно для решения поставленной задачи - определить специфику террора в Грузии, начиная с соотношения социального и этнического его компонентов. В частности, сохранились так называемые расстрельные списки, содержащие немало различной информации (вплоть до технической конкретики исполнения приговоров - «выстрелом в правый висок»). Более того, авторы указывают, что «центральным комплексным источником для изучения этого периода истории республики являются протоколы трех различных троек: «кулацкой», особой («национальной») и милицейской. «В отличие от всех остальных регионов бывшего Советского Союза, - пишут авторы, - эти протоколы троек впервые дают возможность комплексно изучить ядро Большого террора, которое в совокупности образовывали три наиболее массовые карательные акции» [2, с. 31].

Очень важным обстоятельством для правильного подхода к предмету исследования

Дзугаев Коста Георгиевич - к. ф. н., доиент кафедры фрилософрии Юго-Осетинского госуниверситета им. А. А. Тибилова, с. н. с. отдела новой и новейшей истории Юго-Осетинского НИИ им. З. В. Ванеева, заслуженный деятель науки РЮО, гендиректор Центра информационных технологий "Интеллектуальные ресурсы», г. Цхинвал, PЮO (kostadzugaev@ mail.ru).

1 На момент верстания статьи книга вышла в печати; см.: Грузия в пути. Тени сталинизма. сост. М. Юнге, В. Бонвеч, Д. Мюллер. - М.: АИРО-XXI, 2017. 512 c. - Ред. 
авторы считают учет того обстоятельства, что определенная часть прав на ведение карательной политики Москвой была передана на места, в том числе республиканским властям (в данном случае в Тбилиси): «Факт уступки центром своих карательных компетенций периферии, в свою очередь, обещает послужить источником новых сведений об особенностях массовых репрессий в этой специфической советской республике. Не секрет, что Грузия была регионом, который характеризовался значительными межэтническими проблемами» [2, с. 33].

Этничность понимается авторами конструктивистски - отмечу, в отличие от грузинских коллег, в подавляющем большинстве по сей день остающихся на позициях примордиализма, причем часто весьма жесткого. Знаком с ситуацией, так как неоднократно беседовал с грузинскими коллегами-историками в ходе встреч сначала по проекту «Норвежский процесс» (серия грузиноосетинских встреч по инициативе гарвардского профессора Р. Фишера), а затем по проекту «Точка зрения» (аналогичный проект по инициативе профессора С. Нан из университета им. Дж. Мейсона); кроме того, участвовал в подготовке методического пособия «Проблемы и перспективы подготовки учебников и преподавания истории на Южном Кавказе. Методологическое пособие» (2014 год). Что же касается личного понимания современных научных представлений об этничности и нации, то оно формировалось в основном под влиянием работ академика $\mathrm{PAH}$ В. Тишкова и участия в деятельности созданной им одной из лучших в мире экспертно-аналитических структур - Сети этнологического мониторинга и раннего предупреждения конфликтов, в бытность его директором Института этнологии и антропологии РАН.

Авторами четко указываются цели работы с базами данных, перечень целей составляет восемь позиций, в том числе «какие группы (социальные, возрастные, национальные и т. д.) подвергались особенно суровым преследованиям и наиболее жестоко осуждались» [2, с. 59-60].

М. Юнге провел большую и весьма тщательную работу по статистической обработке имеющегося в доступе материала. Мое внимание, с учетом нижеизложенных соображений, не могла не привлечь подглава, посвященная степени интенсивности репрессий (она так и называется). Этот показатель рассчитывается как соотношение численности репрессированных к общей численности населения (либо конкретной изучаемой общности). Численность населения Грузинской Советской Социалистической Республики на то время составляла 3377000 человек, из них по самой массовой, «кулацкой» операции, было репрессировано 21107 человек, что составляет 0,6 \% (из них половина приговорена к высшей мере наказания $(\mathrm{BMH}))$. М. Юнге, однако, на этом не останавливается и делает уточнение, оставаясь в рамках научно добросовестного исследования, что этот процент должен был соотнесен в основном с мужским населением Грузии, т. к. женщины составляли не более $3 \%$ репрессированных. Следующее уточнение, естественно, по возрастной группе - от 20 до 69 лет, и в итоге процент вырастает до 2,3 \%. Далее делается аналогичная обработка данных по «национальной» и «социальной» (милицейской) операциям и выводится конечный процент - 2,74 \%. Но и это еще не все: сюда надо добавить и тех, кто был осужден Военной коллегией Верховного Суда СССР (0,12 \%, или 910 человек в абсолютной величине), жертв военных трибуналов, Специальной коллегии Верховного Суда и Особого совещания и, наконец, лиц, осужденных обычными судами (в совокупности оцениваются на уровне $0,14 \%$ ).

Окончательный показатель степени интенсивности репрессий в Грузии, таким образом, получается 3 \%, из которых свыше 90 \% составляли мужчины указанного возрастного диапазона. Этот показатель М. Юнге оценивает как «катастрофический» [2, с. 73]. Запомним этот термин.

Кроме количественного, М. Юнге провел также качественный анализ: «Качественный анализ репрессий 1937-1938 гг. в Грузии подразумевает изучение и интерпретацию статистических данных жертв трех массовых операций НКВД (операция по приказу № 00447 («кулацкая». - К. Д.), операция по «национальным линиям» и социальная чистка)» [2, с. 89]. Результатом Большого террора в Грузии М. Юнге называет воцарившийся там «кладбищенский покой» - продолжавшийся, однако, недолгое время: репрессии в Грузии отрывочно продолжились после 1941 года, на сей раз управляясь строго из Москвы.

Математически обоснована и такая уникальная в сравнении с остальными республиками СССР особенность Грузии, как очень большой процент осужденных «кулацкой» тройкой членов ВКП(б): 19 \%, или 3347 человек. «Эти цифры позволяют высказать предположение, что бериевский клан использовал массовую операцию НКВД по приказу № 00447 еще и для того, чтобы полностью подчинить себе партийную организацию Грузии и/или избавиться от конкурирующих и критических течений на более низких этажах власти» [2, с. 144]. Подчеркиваю, что этот результат является чрезвычайно важным и для рассмотрения карательной политики Тбилиси в отношении осетин в Грузии в целом и в Южной Осетии в частности. Авторы, увязывая этот аспект проблемы с другим важным аспектом, а именно взаимозаменяемостью карательных ор- 
ганов, делают верный вывод: «Фактически «кулацкая» тройка служила в Грузии не только как внесудебная инстанция для быстрого осуждения простых советских граждан, так называемой «низовки» массовых операций, но и как охотно используемая возможность основательно и без лишнего шума очистить общество от «неудобных» элит» [2, с. 146].

Существенный интерес представляет изучавшийся авторами вопрос о бюрократическом обороте между Тбилиси и Москвой: по их мнению, это были огромные логистические издержки. При этом 8-й отдел ГУГБ НКВД, который большинством исследователей понимается как учетнорегистрационный, и не более того, выявляется и как решающая инстанция. Так, документально отслежено, что именно оттуда в Тбилиси были спущены около трехсот дел, предназначавшихся для рассмотрения Военной коллегией в Москве, но после пересылки в Тбилиси рассмотренных «тройкой», причем практически все приговоры вынесены в точном соответствии с рекомендациями из Москвы. Развивая свою логику исследования, авторы приводят убедительные документальные свидетельства того, что 8-й отдел, по сути вещей, являлся инстанцией, откуда исходили указания по приговорам, которые в дальнейшем лишь оформлялись в Военной коллегии и других судебных и внесудебных инстанциях: «Очевидно, что 8-й отдел (в июне 1938 г. переименован в 1-й спецотдел) имел возможность влиять также на решения Особого совещания, поскольку начальник отдела И.И. Шапиро являлся также начальником секретариата Особого совещания при наркоме внутренних дел СССР с конца марта до середины ноября 1938 года» [2, с. 151]. В этой системе работы умышленно задавался такой порядок работы, при котором НКВД фактически контролировал сам себя, и авторы справедливо считают это преступным обстоятельством. Несущей конструкцией этой системы, как это очевидно, является бюрократия НКВД. Соответственно, реальная власть в стране принадлежала людям, контролирующим эту бюрократию.

Центр требовал быстроты работы карательного аппарата, что имеет свое объяснение общеполитической ситуацией в стране, и это требование порождало неизбежные бюрократически-документальные особенности оформления дел, особенно в «тройках». Исследователи, занимавшиеся работой на данном направлении, всегда испытывали сильные чувства и даже шоковые реакции, впервые беря в руки дела, где смерть человека проистекала буквально из нескольких листов бумаги, с краткими протокольными записями с использованием устоявшихся клише: «Осознание того, что от такого рода протоколов зависела жизнь сотен тысяч людей, действует ошеломляюще» [2, с. 142]. Подтверждаю: да, действует ошеломляюще.

Обратимся теперь непосредственно к главному предмету аналитического комментария - главе «Этнос и террор», которую в первую очередь и предложил рассмотреть М. Юнге.

Над главой «Этнос и террор» работали сам М. Юнге, Даниель Мюллер, Вольфганг Фойерштайн, Иван Джуха.

Исследователи с самого начала подчеркивают ярко выраженный мультиэтнический характер грузинского общества и ставят целью прояснить вопрос: «Имели ли массовые операции НКВД, помимо политической и социальной, также этническую или расистскую компоненту? Возможно, в них даже можно различить структуры геноцида?» [2, с. 208]. Далее приводится ключевое утверждение в отношении абхазов о том, что их при Большом терроре было репрессировано непропорционально много, и указывается на то, что это обстоятельство сыграло и продолжает играть большую роль для сецессии Абхазии из грузинского государства.

Однако сразу вслед за этим авторы пишут: «Скорее против тезиса об этнической составляющей террора выступает то обстоятельство, что на территории Южной Осетии, сегодня также де факто отколовшейся от Грузии - отделение сопровождалось жестокими вооруженными конфоликтами в 1991 и 2008 гг., - было репрессировано относительно немного осетин в сравнении с этническими грузинами» [2, с. 208]. Насколько верно это заключение, и чем оно обосновывается? Постараюсь представить логику рассмотрения и обоснования иной точки зрения.

Авторы указывают (напоминают) на два теоретико-методологических подхода к интерпретации репрессий в отношении национальностей: один исходит из полной индивидуализации причин репрессий, т. е. личностных характеристик репрессируемых или мотиваций лиц, осуществляющих карательную практику (например, известно, что Л. Берия испытывал личную вражду к Н. Лакоба именно как к абхазу), другой видит в национальности ключевой критерий репрессий, аргументируя это не только «национальными» операциями в 1937-1938 годах, но и депортациями народов как апогеем этой карательной политики. Национальность во втором подходе выступает, следовательно, как некоторый объективный фрактор, связываемый с теми или иными причинами - военной опасностью, контактами с заграничными соплеменниками и др., и присваивающий, таким образом, ту или иную меру ответственности выделенным по национальному признаку общностям, т. е. коллективную ответственность. 
Авторы сообщают о своем намерении серьезной корректировки методологии исследования в отношении «узкого и одномерного» понимания этого типа репрессий как «московской» политики: предлагается сдвиг в пользу более объемного рассмотрения карательной политики с включением в круг ее причин интересов местных центров власти, в данном случае власти «тбилисской». Бесспорно, это совершенно необходимая методологическая новация, без которой просто невозможно адекватное описание причин и механизмов Большого террора в Грузии.

Авторы эскизно анализируют представления ряда исследователей, включая и такие, как объяснение размаха репрессий «ксенофобией и паранойей Сталина». Они указывают на весьма примечательный фракт: «Необходимо отметить, что в грузинской историографии полностью отсутствует дискуссия о возможной связи между террором и этничностью. Напрашивается предположение, что такая постановка вопроса, не говоря уже об исследованиях возможной взаимосвязи, противоречила установкам постсоветской, как, впрочем, и советской грузинской историографии, из-за опасения снабдить аргументами конкурирующую историографию национальных меньшинств» [2, с. 216]. Действительно, тема связи этничности и террора тщательно обходилась грузинскими историками и в советское время, и, как бы это странно ни выглядело, в постсоветское время. Авторы, как видно, объясняют это тем, что грузинские историки опасались того, что правда о репрессиях даст неотразимый аргумент национально-освободительным движениям абхазов и осетин - аргумент, предъявление которого международному сообществу, в том числе его политическим и юридическим институциям, неизбежно придаст борьбе этих народов за самоопределение критически значимый уровень легитимации. Действительно, из геноцидного государства надо спасаться любыми средствами.

Авторы настаивают, что тезис об этнизации карательной политики сталинизма не подтвержден документально. Соглашаясь с этим утверждением в целом, т. е. применительно к общесоюзной репрессивной политике, должен, однако, обратить внимание авторов на то, что из этого правила возможны исключения, причем именно в силу обосновываемого ими же положения об особенностях Большого террора в Грузии; т. е. речь может идти об исключениях, подтверждающих общее правило. На мой взгляд, высказываемое авторами мнение, документально подтвержденное исследованными базами данных, о преимущественном репрессировании абхазов по этническому признаку, представляет собой именно исключение из этого общего правила исключение, ставшее возможным как раз в силу изучаемых авторами особенностей карательной политики на местах, вследствие передачи центром части карательных полномочий властям республик, краев и областей СССР.

При этом, анализируя базы данных, авторы с присущей им добросовестностью обнаруживают весьма существенное обстоятельство многие репрессируемые, будучи на самом деле представителями национальных меньшинств, учетным порядком причислялись к грузинам на основании «механической» идентификации по именам. Об этом обстоятельстве авторы сообщают вполне ясно: «Таким образом, доля грузин среди репрессированных очевидно является завышенной, а доля национальных меньшинств - соответственно заниженной. Размер этой погрешности установить невозможно, однако по меньшей мере это означает, что те статистические сведения о репрессиях в отношении национальных меньшинств, которые приведены в базах данных, представляют собой нижнюю границу. Эта граница предположительно может быть сдвинута вверх, для каждой отдельной национальности по-разному, лишь в результате более тщательного изучения следственных дел около 25000 жертв массовых репрессий в Грузии» [2, с. 220]. Считаю этот вывод особо важным именно для ситуации с осетинами, так как ассимиляционная политика грузинских властей в отношении осетин давно и хорошо изучена и описана: этнический осетин с написанием в документах своей фрамилии не с русскими окончаниями, а с грузинскими («-швили», «-дзе», «-ури» и др.), часто автоматически учитывался в грузинской статистике уже как грузин по национальности, и, таким образом, число репрессированных осетин весьма существенно может и должно быть увеличено - по моим оценкам, от полутора до двух раз. Насколько мне известно, абхазы гораздо жестче относились к этому аспекту своих взаимоотношений с грузинами, и там такого рода случаи гораздо более редки.

Авторы расписывают и непосредственную технологию исследования, разбивая ее на пять этапов, и достаточно четко указывают цель каждого этапа. Этим достигается такое качество научной работы в подлинном смысле этого слова, как прозрачность и проверяемость. Иными словами, они максимально ясно показывают всем заинтересованным лицам и организациям свое стремление к коллегиальному обсуждению изучаемой тематики и свою готовность к диалогу по любому конкретному вопросу, будучи при этом готовыми как к аргументированному отстаиванию своих выводов, так и к признанию ошибок в случае конструктивной критики сугубо научным порядком.

Начинают свой анализ авторы, естественно, с грузин как титульной нации. Пожалуй, здесь их 
научная добросовестность имеет одно из наиболее показательных проявлений, так как они ставят необходимый методологический вопрос о том, как понимать в целях анализа карательной политики сам термин «грузины». Они отмечают, что «бюрократия карательных органов объединяла под рубрикой «грузины» не только этнографические или, соответственно, племенные подгруппы (субэтносы) грузин, такие как картлийцы, кахетинцы, тушинцы, пшавы, хевсуры, ингилойцы, месхетинцы, имеретинцы, гурийцы, рачинцы и лечхумцы, но и мингрелов, сванов и бацбийцев (цова-тушинов)» [2, с. 224]. Они указывают, что не обнаружили и, следовательно, не располагают документами, объясняющими, почему грузинская (карательная) бюрократия включила в состав грузин мингрелов, сванов и бацбийцев (цова-тушинов); однако несомненно, что преследовалась цель достижения языкового единообразия, резкого сокращения национального разнообразия - так, еще в конце XIX века даже «мингрельский язык был объявлен диалектом грузинского и был поставлен заслон на пути попыток со стороны России ввести мингрельский в качестве языка преподавания в школе» [2, с. 226]. Грузинское чиновничество проигнорировало и рекомендации Комиссии Академии Наук СССР по учету национального состава СССР, в результате 300000 мингрелов попросту исчезли из статистики, равно как и из позитивной культурной политики.

Авторы подробно изучают в этом отношении ситуацию с лазами - они, в отличие от аджарцев, мингрелов и сванов, продолжали фригурировать в базах данных по репрессиям. Такое исключение объясняется, во-первых, тем, что лазы соединили в себе два главных отличительных признака - говорили на собственном, а не грузинском языке, и являлись мусульманами; во-вторых, они выступали естественными политическими союзниками в борьбе абхазского руководства против тбилисского центра. Как яркую иллюстрацию авторы приводят примеры активности одного из лидеров лазов Искандера Циташи, который в ряде писем в центральные инстанции прямо обвиняет ЦК КП Грузии в проведении неформальной политики грузинизации, описывая ее конкретные проявления в отношении лазов, чье положение он характеризует как «перманентную катастрофу». Разумеется, такое не могло быть прощено, и в июне 1938 года по личному письменному распоряжению Л. Берии [2, с. 237] А. Циташи был арестован и расстрелян. Добавлю, что авторы указывают на аналогичную судьбу мингрельца Исаака Жвании, расстрелянного в декабре 1937 года, однако оговариваются, что по сохранившимся документам трудно или невозможно сделать достоверный вывод о репрессии его имен- но по национальному признаку. На мой взгляд, хорошо известные факты его биографии позволяют сделать такой вывод, так как И. Жвания был мингрелом-патриотом, имел тесные связи с Н. Лакобой и поддерживал стремление абхазов к включению в состав РСФСР, а кроме того, работал первым секретарем Юго-Осетинского областного комитета КП Грузии в 1932-1934 годах и отличился решительным отстаиванием прав южных осетин. Очевидно, что он был одним из видных представителей неформального «общего фронта» национальных меньшинств против политики «грузинизации».

Остается добавить, что степень интенсивности репрессий лазов составляет исключительно высокие 3 \%, причем к ВМН приговорено почти в два раза больше лазов (в процентном отношении), чем грузин.

Подглава 5 посвящена ситуации с абхазами, аджарцами и осетинами.

По Абхазии дается полная информация об автохтонности абхазов, административно-политических перипетиях абхазской республики, замалчивании истории понижения, т. е. репрессиях, статусе республики: «Что же касается историографии в Грузии, то она поддалась искушению национализма и не стремилась предоставлять абхазам какие-либо аргументы в пользу независимости Абхазии» [2, с. 246].

По осетинам в пояснительной части обозначается, выявляется некая неясность, расплывчатость в плане технологии анализа, если оставаться на заявленных авторами методологических позициях. Так, пишется о том, что «на территориях, на которые притязает Грузия, осетины не проживают компактными группами: в Юго-Осетинской автономной области, созданной в 1921 г., осетины составляли две трети населения (около 70000 из 100 000), однако еще примерно столько же осетин проживало вокруг автономной области, среди грузинского населения в Картли-Кахетии» [2, с. 247].

Здесь тем самым явочным порядком задается, несмотря на упоминание ЮОАО, рассмотрение ситуации с осетинами в общегрузинском контексте. Такой посыл с неизбежностью приводит к ошибкам в оценках степени интенсивности репрессий в отношении осетин, тем более грубым, чем более последовательно он проводится.

Что означает, в точном смысле, словосочетание «не проживают компактными группами» применительно к осетинам? Ведь осетины Юга Осетии - часть (южная) единого народа, проживающего по обе стороны Главного Кавказского хребта на своей этнотерриториальной родине, что обширно документировано грузинскими же источниками, а также, разумеется, российскими, армянскими и другими. Впрочем, современная 
грузинская историография и опирающаяся на нее политическая доктрина грузинского государства со времен 3. Гамсахурдиа по сегодняшний день не желает признавать существования народа, проживающего на своей территории и отказывающегося участвовать в грузинском государственном этнопроекте.

Указанная нечеткость начальных позиций приводит, при всей добросовестности авторов, к весьма показательным цифровым аберрациям. Так, по «кулацкой» операции (приказ № 00447) приводится общая для «полутитульных» абхазов и осетин цифра - 895 человек, из них 554 абхазов (62 \%); их доля в общем числе репрессированных составила 4,2 \% (абхазы 2,6 \%, осетины 1,8 \%). Далее авторы подчеркивают, что если брать абхазов отдельно, то бросается в глаза резкое превышение степени интенсивности репрессий по сравнению с грузинами: $1 \%$ у абхазов против 0,63 \% у грузин. По смертным приговорам: 0,57 $\%$ у абхазов и 0,30 \% у грузин.

И вот закономерная констатация: «Однако смущает то обстоятельство, что степень репрессий в отношении абхазов существенно отличается от соответствующего показателя для осетин, хотя в обоих случаях речь идет о «полутитульных» нациях, имевших свои автономные республики или области в составе Грузии. Как уже указывалось выше, абсолютное число репрессированных осетин было меньше, чем число жертв среди абхазов. Если же посчитать степень репрессий в отношении осетин, т. е. вычислить соотношение числа жертв к численности осетин в Грузии, то разница будет особенно очевидной» [2, с. 249]. В цифррах степень репрессий против осетин составила в такой оптике «только» 0,24 \%, что составляет лишь четвертую часть от абхазского показателя. «Поразительным образом, - удивляются авторы, - осетин репрессировали менее интенсивно не только в сравнении с абхазами, но и в сравнении с титульной нацией - грузинами, а именно в соотношении $0,4: 1$ $(0,24 \%: 0,63 \%) »[2$, с. 249]. Такие цифры получаются, если исходить из тогдашней численности осетин в Грузии в 143604 осетина. В ссылке № 107 делается добавление, что «в Юго-Осетинской автономной области проживало 87358 человек, большинство из них составляли осетины. См.: Всесоюзная перепись населения 1937 года. С. 46». Добавлю, что по переписи 1926 года в ЮОАО проживало 87375 человек, из них 60 351 осетин (69,07\%), 23538 грузин (26,94 \%), по переписи 1939 года - 106118 человек (наивысшая численность за все время существова- ния ЮОАО, впоследствии всегда менее 100000 человек), из них осетин 72266 (68,10\%), грузин 27525 (25,94 \%)[17]. Отсюда можно сделать обоснованный вывод, что из 87358 человек по переписи 1937 года, на которую ссылаются авторы, те же 70 \% составляли осетины, т. е. 61150 человек (грузин в таком случае усредним до 26 \%, что дает 22713 человек). Примем эти цифры за точки отсчета, они репрезентативны даже при весьма скрупулезном подходе к арифметике репрессий.

Авторы, что и говорить, пытаются рационально, стараясь оставаться в заданных параметрах исследования, объяснить такую «поразительную» разницу. Их рабочая гипотеза заключается в том, что эти две этнические общности имели сильно различающийся политический и социальный статус (по происхождению и на момент ареста). К сожалению, неверное методологическое начало рассмотрения ситуации с осетинами «в целом», несмотря на все старания авторов аргументировать свои соображения приводимыми материалами из используемых баз данных, к научно значимому положительному результату в данном случае привести не могло; оперирование цифрами в этом отношении зачастую не проясняло, а затемняло реальную картину, иногда приближаясь к оторванной от существа вопроса цифровой эквилибристике.

Между тем для того, чтобы все встало на свои места, нужно сделать одно и только одно, но необходимое методологическое усилие; при этом оно исходит из общей логики научного исследования самих авторов, и естественно укладывается в их, если можно так выразиться, научномировоззренческую парадигму - и мне, честно говоря, остается непонятным, почему этого не было сделано именно в отношении осетин.

Нужно всего лишь взять в качестве объекта анализа саму Юго-Осетинскую автономную область, с осетинами, в ней проживающими (точно так, как это сделано в отношении абхазов). Тогда картина резко меняется и приобретает сущностную аналогию с ситуацией в отношении абхазов.

Работая ряд лет руководителем группы переговорщиков в урегулировании грузино-осетинского конфликта ${ }^{1}$, мне не раз приходилось убеждаться в необходимости научного сопровождения процесса урегулирования; эта задача касалась в первую очередь взаимно проблемных вопросов истории двух соседних народов. Тогда, во второй половине 90-х годов XX века, мне пришлось впервые лично заняться и обсуждаемой здесь проблематикой - репрессиями 1937-1938

${ }^{1}$ В частности, я был ответственным лицом с югоосетинской стороны за текстуальную подготовку и политическое обеспечение Меморандума о мерах по обеспечению безопасности и укреплению взаимного доверия между сторонами в грузино-осетинском конфрликте, подписанного в Москве 16 мая 1996 года и признанного уникальным, прорывным документом для всех «горячих точек» на территории бывшего СССР (http://www.osetinfo.ru/conf904). 
годов в Южной Осетии. Впоследствии, вынужденный заняться исторической проблематикой профессионально, мне пришлось значительную часть научной деятельности посвятить разработке этой темы - как выяснилось, совершенно неизученной и потому порождающей негативные последствия и в грузино-осетинских отношениях, и в самом югоосетинском обществе. Определенные результаты изложены в моей (с доктором исторических наук В. Дзидзоевым) монографии [9].

Ранее меня этой табуированной темой занимался Владимир Ванеев, сам пострадавший от грузинской карательной политики в отношении южных осетин. Им в 2005 году была издана работа «Люди, помните о нас» ${ }^{2}$ [3], где он дал пионерную публичную информацию об этом темном и трагическом периоде новой истории южных осетин. В этой работе впервые сделана попытка не только описать репрессии как таковые, с их социальным фооном и последствиями, но и представить количественные данные.

С 2014 года, изучая (в числе прочих) вопрос о репрессиях в ЮОАО, я занялся сплошной проработкой бывшего Партийного архива ЮгоОсетинского областного комитета КП Грузии, а ныне Политического отдела Центрального Государственного Архива Республики Южная Осетия (ПО ЦГА РЮО), и к настоящему времени проштудировал эти анналы до 1940 года. Информация, почерпнутая в ходе этой архивной работы, о репрессиях в ЮОАО, оказалась не столь объемной, как ожидалось и хотелось бы, но все же вполне достаточной для того, чтобы сделать достоверные, хорошо подтверждаемые выводы об особенностях карательной политики грузинских властей в Южной Осетии.

Имеющийся в ПО ЦГА РЮО «Список репрессированных в 1937-1938 г. г.» [13, л. 38-75] содержит 330 имен; этот список назовем первым. Впоследствии стараниями работников архива список пополнялся, и в настоящее время к указанному делу прилагается отдельная папка под названием «Список лиц, репрессированных и реабилитированных в 1937-1938 гг.» (название содержит неточность, так как значительная часть реабилитированных дел относится к более позднему времени, вплоть до 1991 года); этот список пусть будет второй. Дополненный список содержит 375 имен, однако два человека повторяются дважды вследствие механических ошибок (Гатенов Григорий Ильич (№№ 79 и 93) и Плиев Арсен Александрович (№№ 274 и 276 (на последующей странице)), поэтому правильное количество имен - 373.

Поименный анализ по второму списку дал следующий результат:

осетин - 216 человек, что составляет 57,91\% из указанного числа репрессированных, и 0,61\% от осетин ЮОАО; из них расстреляно 96 человек $(44,44 \%)$, к 10 годам лагерей 88 человек (40,74 $\%)$, остальные к более мягкому наказанию;

грузин - 105 человек, что составляет 29,62 \% от репрессированных, и 0,42 \% от грузин ЮОАО; из них расстреляно 23 человека (21,90\%), к 10 годам лагерей 64 человека (60,95 \%), остальные к более мягкому наказанию.

Из оставшихся распределение по национальностям идет, начиная с евреев, затем армяне, русские и другие; анализ по оставшемуся массиву не входит в задачи данной публикации.

Следует сделать важное пояснение к осетинским и грузинским спискам: рассматривая фамилии с осетинским корнем и грузинским окончанием, в данном случае принято решение отнести их к грузинам. Речь идет о четырех представителях фамилии Басишвили и одном - Гаглошвили. Прямых указаний на их национальную идентификацию пока не обнаружено; эти люди, скорее всего, причисляли себя к осетинам ${ }^{3}$, но в отсутствие надежных биографических данных я по формальному признаку учел их в качестве грузин.

Кроме того, очевидно, что и второй список репрессированных жителей Юго-Осетинской автономной области заведомо и существенно неполон. По сообщению начальника ПО ЦГА РЮО Ю. Лалиевой, глубоко изучившей ситуацию с репрессиями по долгу службы (ныне на пенсии), десятки людей арестовывались и, соответственно, оформлялись за пределами Юго-Осетинской $\mathrm{AO}$, а некоторая ощутимая часть и за пределами Грузинской ССР, т. е. эта часть не попадала и в общегрузинскую статистику по осетинам. Косвенно предположение о неполноте списка подтверждается и тем, что процент репрессированных осетин в ЮОАО - менее $60 \%$, в то время как в численности населения они составляют $70 \%$ (или чуть меньше); между тем вся сумма сведений о репрессиях в Южной Осетии - и пря-

2 В. Ванеев, ныне от нас ушедший, работал сотрудником Юго-Осетинского НИИ. В 2012 г. мне довелось помочь ему е качестве наборщика и редактора подготовить автобиографическое издание (Ванеев В. Белые облака на черном небосклоне (воспоминания). Цхинвал, 2012), где он описывает не только трагические изломы своей личной судьбы, но и судьбь своих друзей из подпольной организации «Рæстдзинад» ("Справедливость»), боровшейся против ущемления осетинского языка и культуры со стороны грузинских властей: с ними расправились в 1951 году, не пощадив даже школьника (10 лет тюрьмы).

${ }^{3}$ У меня есть родственники Басишвили, нынешнее поколение причисляет себя к грузинам, но еще два поколения назад, $m$. е. как раз в рассматриваемое время, они были обычными осетинами с грузинским окончанием фамилий; проживали они в грузинской среде, потому и совершился дрейср идентичности. 
мых сведений, и косвенных - подводит к выводу о том, что процент репрессированных осетин должен составлять по меньшей мере одинаковую пропорцию с процентом численности населения, а скорее всего, должен ее превосходить. Аналогичное утверждение справедливо и для процента приговоренных к ВМН: несомненно, в реальности она превышает $50 \%$, и я уверен, что по мере дальнейшей работы по этой теме это предположение получит документальное подтверждение.

Касательно возможных дополнений к списку репрессированных следует также отметить, что В. Ванеев, по-видимому, располагал несколько более полной информацией о репрессиях и репрессированных, так как работавший с ним и написавший предисловие к его книге исследователь Ю. Цховребов, проведя пофамильный анализ (что для осетинского менталитета очень важно), пишет о 94 фамилиях, имеющих в своем составе репрессированных, из них, например, у Цховребовых 14 человек (в имеющемся в ПО ЦГА РЮО втором списке - лишь 9), у Санакоевых 13 (в списке - 14), у Гассиевых 8 (в списке - 7), у Джиоевых 8 (в списке - 6) и т. д. К сожалению, личный архив В. Ванеева пока недоступен.

В отдельном пояснении также нуждается, видимо, абзац авторов о курьезном, по их мнению, аспекте: «Курьез состоит в том, что в случае с осетинами, осужденными «милицейской тройкой», 10 \% получили свои сроки как бывшие меньшевики. Очевидно, со стороны Москвы последовало какое-то напоминание о том, что осетины не всегда последовательно сражались на стороне большевиков против «меньшевистской Грузии» [2, с. 256-257]. Дело здесь, по моему мнению, в том, что к меньшевикам из этих $10 \%$ в подавляющем большинстве относились осетины, проживавшие и арестованные в Грузии за пределами Южной Осетии; в самой Южной Осетии осетин-меньшевиков было ничтожное количество, и по изучаемому списку таковых обнаружилось лишь двое, да и по ним их реальная принадлежность к меньшевикам вызывает большое сомнение; скорее всего, это было искусственное приписывание с целью формального обоснования репрессии. Иными словами, фраза о том, что «осетины не всегда последовательно сражались на стороне большевиков», если и имеет хоть какой-то смысл, то лишь в отношении осетин в районах Грузии; что касается осетин Южной Осетии, то здесь для понимания истинных причин столь жестоких репрессий надо знать политическую историю южных осетин хотя бы в узловых ее моментах. Здесь тоже надлежит совершить такой же исторический экскурс, какой был сделан для прояснения ситуации с абхазами - и это было верным решением авторов, которым почему-то были обойдены осетины.

\section{(Окончание следует)}

\section{ЛИТЕРАТУРА}

1. Блиев М.М. Южная Осетия в коллизиях российско-грузинских отношений. - М., 2006. С. 238.

2. Большевистский порядок в Грузии. Издание в 2 томах. Составители Марк Юнге, Бернд Бонвеч. - М., 2015. 640 с. (Макет представлен в электронном виде)

3. Ванеев В.Д. Люди, помните о нас. - Цхинвал, 2005. 182 с. 4. Гаглойти Ю.С. Аланы и вопросы этногенеза осетин. Тбилиси, 1966.

5. Гаглойти Ю.С. Алано-Георгика. Сведения грузинских источников об Осетии и осетинах. - Владикавказ, 2007.

6. Гаглойти Ю.С. Избранные труды. Т. 1. - Цхинвал, 2010 (составитель и научный редактор Дзугаев К. Г.).

7. Джугели В. Тяжелый крестъ. Записки Народногвардейиа. - Тифрлисъ, 1920 (http://iarir.ru/node/61).

8. Дзидзоев В.Д., Дзугаев К.Г. 1937 год в Южной Осетии // Вестник Владикавказского научного центра. Том. 7. № 1. 2007. C. 23-30.

9. Дзидзоев В.Д., Дзугаев К.Г. Южная Осетия в ретроспективе грузино-осетинских отношений. Цхинвал, 2007. 271 с.
10. Дзидзоев В.Д., Дзугаев К.Г. Сослан-Давид Царазон в истории Грузии и Осетии: фракты и гипотезы // Дарьял, № 2.- Владикавказ, 2007. С. 159-175 (в соавторстве с В.Д. Дзидзоевым); в эл. доступе http://iarir.ru/node/97.

11. Книга Памяти. Т. 3. - Владикавказ, 1995.

12. Орджоникидзе Г.К. Статьи и речи. Т. 1. 1910-1926 ге. M., 1956.

13. Политический отдел Центрального Государственного Архива Республики Южная Осетия. Ф. 1, оп. 2, кор. 18, d. 205.

14. Хронология исторических событий // История ЮгоОсетии в документах и материалах (1800-1864 ге. Составитель И. Н. Цховребов. Т. 2. - Сталинир (ныне Цхинвал), 1960. C. 646-647).

15. Цховребов Ю.В. Южная Осетия и трагический 1937 год // Ванеев В. Д. Люди... С. 7 (предисловие к книге).

16. ... Чтобы не достались врагу // Социал-демократ Осетии. 2002, август, № 11.

17. https://ru.wikipedia.org/wiki/Население_Южной_Осетии. 


\title{
SOUTH OSSETIA AND GREAT TERROR IN SOVIET GEORGIA
}

\author{
K.G. Dzugaev
}

PhD, Associate Professor. South Ossetian State University named after A.A.Tibilov.

Abstrakt. The article deals with the specificity of the repression during 1937-1938 in South Ossetia, the quantitative and qualitative analysis of the available data is being carried out , the article concludes that the Georgian authorities had benefited during the period of the Great Terror to suppress the South Ossetian national movement.

Keywords: Repression, Georgia, South Ossetia, 1937 year.

\section{REFERENCES}

1. Bliev M.M. Yuzhnaya Osetiya v kolliziyakh rossiysko-gruzinskikh otnosheniy. - M., 2006. S. 238

2. Bol'shevistskiy poryadok v Gruzii. Izdanie v 2 tomakh. Sostaviteli Mark Yunge, Bernd Bonvech. - M., 2015. 640 s. (Maket predstavlen v elektronnom vide)

3. Vaneev V.D. Lyudi, pomnite o nas. - Tskhinval, 2005. 182 s.

4. Gagloyti Yu.S. Alany i voprosy etnogeneza osetin. - Tbilisi, 1966.

5. Gagloyti Yu.S. Alano-Georgika. Svedeniya gruzinskikh istochnikov ob Osetii i osetinakh. - Vladikavkaz, 2007.

6. Gagloyti Yu.S. Izbrannye trudy. T. 1. - Tskhinval, 2010 (sostavitel'i nauchnyy redaktor Dzugaev K. G.).

7. Dzhugeli V. Tyazhelyy krest". Zapiski Narodnogvardeytsa. - Tiflis", 1920 (http://iarir. ru/node/61)

8. Dzidzoev V.D., Dzugaev K.G. 1937 god v Yuzhnoy Osetii // Vestnik Vladikavkazskogo nauchnogo tsentra. Tom. 7. № 1. 2007. S. 23-30.

9. Dzidzoev V.D., Dzugaev K.G. Yuzhnaya Osetiya v retrospektive gruzino-osetinskikh otnosheniy. Tskhinval, 2007. $271 \mathrm{~s}$.

10. Dzidzoev V.D., Dzugaev K.G. Soslan-David Tsarazon v istorii Gruzii i Osetii: fakty i gipotezy // Dar'yal, № 2.- Vladikavkaz, 2007. S. 159-175 (v soavtorstve S V.D. Dzidzoevym); v el. dostupe http://iarir.ru/node/97.

11. Kniga Pamyati. T. 3. - Vladikavkaz, 1995.

12. Ordzhonikidze G.K. Stat'i i rechi. T. 1. 1910-1926 gg. M., 1956.

13. Politicheskiy otdel Tsentral'nogo Gosudarstvennogo Arkhiva Respubliki Yuzhnaya Osetiya. F. 1, op. 2, kor. 18, d. 205.

14. Khronologiya istoricheskikh sobytiy // Istoriya Yugo-Osetii v dokumentakh i materialakh (1800-1864 gg. Sostavitel' I. N. Tskhovrebov. T. 2. - Stalinir (nyne Tskhinval), 1960. S. 646-647).

15. Tskhovrebov Yu.V. Yuzhnaya Osetiya i tragicheskiy 1937 god // Vaneev V. D. Lyudi... S. 7 (predislovie k knige).

16. ...Chtoby ne dostalis' vragu // Sotsial-demokrat Osetii. 2002, avgust, № 11

17. https://ru.wikipedia.org/wiki/Naselenie_Yuzhnoy_Osetii.

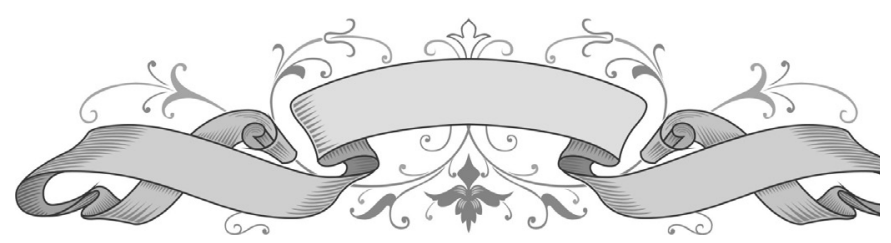

